\title{
CHARACTERIZATION OF PHYSICAL ACTIVITIES PERFORMED BY ADOLESCENTS FROM CURITIBA, BRAZIL
}

\author{
CARACTERIZAÇÃO DAS ATIVIDADES FÍSICAS REALIZADAS PORADOLESCENTES DE CURITIBA, BRASIL
}

CARACTERIZACIÓN DE LAS ACTIVIDADES FÍSICAS REALIZADAS POR ADOLESCENTES DECURITIBA, BRASIL

Original Article

ARTIGO ORIGINAL Artículo Original
Alexandre Augusto de Paula da Silva

(Physical Education Professional)

Edina Maria de Camargo 1,2

(Physical Education Professional)

Alice Tatiane da Silva1,3

(Physical Education Professional)

Jeruza Sech Buck Silva'

(Physical Education Professional)

Adriano Akira Ferreira Hino 1,4,5

(Physical Education Professional)

Rodrigo Siqueira Reis 1,6,7

(Physical Education Professional)

1. Pontifícia Universidade Católica do Paraná (PUCPR), Physical Activity and Quality of Life Research Group (GPAQ), Curitiba, PR, Brazil.

2. Universidade Federal do Paraná (UFPR), Centro de Estudos em Atividade Física e Saúde (CEAFS). Biological Sciences Department, Postgraduate Program in Physical 4 Education, Curitiba, PR, Brazil. 3. Secretaria Municipal de Esporte e Lazer (SEMEL), Department of Leisure. São José dos Pinhais, PR, Brazil.

4. Pontifícia Universidade Católica do Paraná (PUCPR), Escola Politécnica, Postgraduate Program in Health Technology (PPGTS), Curitiba, Paraná, Brazil.

5. Universidade Federal Tecnológica do Paraná (UTFPR), Postgraduate Program in Physical Education,

Curitiba, Paraná, Brazil.

6. Pontifícia Universidade Católica do Paraná (PUCPR), School of Architecture, Postgraduate Program in Urban Management (PPGTU),

Curitiba, Paraná, Brazil.

7. Washington University in St. Louis, Brown School, Prevention Research Center, Saint Louis, Missouri, United States of America.

\section{Correspondência:}

Alexandre Augusto de Paula da Silva. Pontifícia Universidade Católica do Paraná (PUCPR), Physical Activity and Quality of Life Research Group (GPAQ). Rua Imaculada Conceição, 1155, Prado Velho, Curitiba, PR, Brazil. 80215-901. alexandre_03_19@hotmail.com

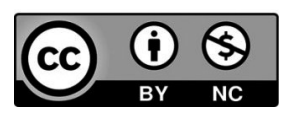

\begin{abstract}
Introduction: Various studies have been developed and published in relation to the recommendations for physical activity and associated factors. However, there is a lack of studies that detail the places where physical activity is practiced, as well as its frequency, duration and volume. Objective: To describe the places, types, frequency, duration and volume of physical activities performed by adolescents in Curitiba, Brazil. Methods: A cross-sectional study conducted in 2013-2014, through a household survey with 495 adolescents (12 to 17 years). The places used, and the frequencies of the practice of physical activity were self-reported as either "goes" or "does not go." The practice of physical activity was determined through the Physical Activity Questionnaire for Adolescents, by type, frequency, duration and weekly volume. The types of physical activity were described with frequency distribution, weekly frequency, duration, and volume, by the median and interquartile range. Gender comparison was tested with the Chi-square and Mann-Whitney $U$ tests $(p<0.05)$. Results: The most frequently reported places for physical activity were public squares, parks, soccer fields, schools and sports halls. Soccer fields, schools, sports halls and skate parks were more used by boys, while girls attended gyms $(p<0.05)$. The physical activities most practiced were soccer, skating/rollerblading, cycling, walking and active games. A higher proportion of boys practiced soccer, skating/ rollerblading, cycling, running/jogging, and basketball ( $p<0.05$ ), whereas the physical activities most practiced by girls were walking, walking the dog, dancing, playing games, and gyms ( $p<0.05$ ). Sports ( $720 \mathrm{~min} /$ week), aerobic exercises ( $400 \mathrm{~min} /$ week) and conditioning exercises (345 min/week) were the activities with the highest weekly volume. Boys showed higher weekly frequency, duration and volume of practice of sports and active games than girls $(p<0.05)$. Conclusion: Public places with structures were the most used places, and sports were the most practiced activities.
\end{abstract} Level of Evidence III; Study of nonconsecutive patients; without consistently applied "gold" reference standard.

Keywords: Exercise; Adolescent; Leisure Activities; Epidemiologic studies.

\section{RESUMO}

Introdução: Vários estudos sobre as recomendações de atividade física e fatores associados têm sido desenvolvidos e publicados. No entanto, faltam estudos que detalhem os locais para prática de atividade físicas, além da frequência, duração evolume. Objetivo: Descrever os locais, tipos, frequência, duração e volume das atividades físicas realizadas por adolescentes de Curitiba, Brasil. Métodos: Estudo transversal realizado entre 2013-2014, por meio de inquérito domiciliar com 495 adolescentes (12 a 17 anos). Os locais para prática de atividades físicas foram autorrelatados de acordo com a frequência semanal e divididos em "não frequenta" "e frequenta". A prática de a tividade física foi obtida por meio do Questionário de Atividade Física para Adolescentes por tipo, frequência, duração e volume semanal. Os tipos de atividade física foram descritos com a distribuição de frequências, e a frequência, a duração e o volume, pela mediana e amplitude interquartílica. A comparação entre os sexos foi realizada com os testes de Qui-quadrado U U de Mann-Whitney $(p<0,05)$. Resultados: Os locais mais relatados para a prática foram praças, parques, campos de futebol, escolas e ginásios de esportes. Campos de futebol, escolas, ginásiose pistas de skateforam mais utilizados por meninos, enquanto meninas utilizavam mais as academias $(p<0,05)$. As atividades fisicas mais praticadas foram futebol, skate/patins, ciclismo, caminhada e games ativos. Uma proporção maior de meninos praticavam futebol, skate/patins, ciclismo, corrida/trotee basquete $(p<0,05)$ enquanto as meninas realizavam caminhada, passeio com cães, dança, jogos e brincadeiras e ginástica de academia $(p<0,05)$. Os esportes ( $720 \mathrm{~min} / \mathrm{semana})$, exercícios aeróbicos (400 min/semana) e de condicionamento (345 min/semana) foram as atividades com maior volume semanal. Os meninos apresentaram maior frequência, duração e volume de prática de esportes e games ativos do que as meninas ( $p<$ 0,05). Conclusão: Locais públicos e com estruturas foram os mais utilizados e atividades esportivas as mais praticadas. Nível de Evidência III; Estudo de pacientes não consecutivos; sem padrão de referência "ouro" aplicado uniformemente.

Descritores: Exercício; Adolescente; Atividades de Lazer; Estudos epidemiológicos.

\section{RESUMEN}

Introducción: Varios estudios sobre las recomendaciones de actividad física y factores asociados han sido desarrollados y publicados. Sin embargo, faltan estudios que detallan los lugares para la práctica actividad física, además de la frecuencia, la duración y el volumen. Objetivo: Describir los lugares, tipos, frecuencia, duración y volumen de las actividades fisicas realizadas por adolescentes de Curitiba, Brasil. Métodos: Estudio transversal realizado entre 2013 y 2014, por medio de encuesta domiciliar con 495 adolescentes (12 a 17 años). Los locales para la práctica de actividades fisicas fueron auto-relatados de acuerdo con la frecuencia semanal y divididos en "No frecuenta" y "frecuenta". 
La práctica de actividad física fue obtenida por medio del Cuestionario de Actividad Física para Adolescentes por tipo, frecuencia, duración y volumen semanal. Los tipos de actividad física fueron descritos con la distribución de frecuencias y la frecuencia semanal, la duración y el volumen, por la mediana y la amplitud interquartílica. La comparación entre los sexos se realizó con Qui-cuadrado y U de Mann-Whitney ( $p<0,05)$. Resultados: Los lugares más relatados fueron plazas, parques, campos de fútbol, escuelas y gimnasios de deportes. Los campos de fútbol, escuelas, gimnasios y pistas de skate fueron más utilizados por niños, mientras que las niñas utilizaban más gimnasios $(p<0,05)$. Las actividades físicas más practicadas fueron fútbol, skate/patines, ciclismo, caminata y juegos electrónicos activos. Una proporción mayor de niños practicaban fútbol, skatel patines, ciclismo, carrera/trotey baloncesto ( $p<0,05)$, mientras las niñas realizaban caminata, pasear con perros, baile, juegos y juguetes y ejercicio en gimnasios ( $p<0,05$ ). Los deportes (720 min/semana), ejercicios aeróbicos (400 min/semana) y de acondicionamiento (345 min/semana) fueron las actividades con mayor volumen semanal. Los niños presentaron mayor frecuencia semanal, duración y volumen de práctica de deportes y juegos electrónicos activos que las niñas $(p<0,05)$. Conclusión: Lugares públicos y con estructuras fueron los más utilizados y las actividades deportivas fueron más practicadas. Nivel de evidencia III; Estudio de pacientes no consecutivos; sin el estándar de referencia 'oro' aplicado constantemente.

Descriptores: Ejercicio; Adolescente; Actividades Recreativas; Estudios epidemiológicos.

\section{INTRODUCTION}

Regular physical activity (PA) during childhood and adolescence is associated with multiple health benefits ${ }^{1}$ and greater chances of remain active in adulthood. ${ }^{2}$ National estimates indicate that $25.0 \%$ of adolescents do not practice any physical activity and $50 \%$ do not exercise at the recommended levels. ${ }^{3,4}$ The preference of children and adolescents for sports activities is predominant in the Americas (10.8\%-39.0\%) and Europe (5.0\%-28.5\%), while in Asia, aerobic activities such as walking/running or cycling (38.1\%-23.5\%). ${ }^{5}$ In Brazil, sports activities, mainly soccer, were the most reported ones. ${ }^{6,7}$

Despite the importance of identifying the prevalence of physical activity at recommended levels ${ }^{8}$ and the associated factors, ${ }^{9}$ studies that identified the types of activities focused on describing the type and frequency of physical activities, failing to describe the volume of practice and the places where they are held. It should be pointed out that characteristics of urban planning ${ }^{10}$ proximity and availability of places have an important role in facilitating such practice. ${ }^{11-13}$

Describing the sites, types, and frequency of physical activities performed by adolescents is an important step towards promoting more active behaviors in view of the potential of promoting more effective and evidence-based interventions., $, 7,14,15$ The objective of this study was to describe the places, types, weekly frequency, duration and volume of physical activities performed by adolescents from Curitiba, Brazil.

\section{MATERIAL AND METHODS}

The data from this study are part of the International Physical Activity and the Environment Network (IPEN) project (www.ipenproject.org). In Brazil, data collections were carried out in Curitiba-PR from August/2013 to May/2014. The study presents a cross-sectional design by means of a household survey. Complementary information can be found in the literature. $^{16}$ The project has been approved by the Research Ethics Committee of PUCPR (135-945/2012). All participants signed an Informed Consent Form.

In Curitiba, there were 2,395 census tracts considered primary sampling units and they were selected for their walkability characteristics and local income. ${ }^{16}$ In order to maximize the variability of walkability and income, the tracts were classified into deciles for both variables. The tracts located at the four extremes (low/high) of walkability and income were selected. In total, 32 census tracts were intentionally selected so that all four groups were represented (eight tracts in each group).

The street segments were listed in all the blocks of the census tracts clockwise. In case of refusal or no adolescent living in the household, the next residence on the left was approached. In each household, one adolescent and their guardian were selected. The criteria for the selection of adolescents were younger girls and older boys, to allow for fair selection of sexes. If the selected adolescent refused to participate in the study, another adolescent from the household could be intentionally selected. Altogether, 589 adolescents were recruited.

Adolescents aged 12-17, living in the census tracts for at least one year prior to the date of collection and attending school were included. Those with some physical and/or cognitive limitation that prevented physical activity were excluded. Theoretical and practical training involved 23 interviewers, undergraduate and graduate Physical Education students, lasting 12 hours, including visiting the households and talking to the participants, selecting, interviewing, filling out forms and refusals.

\section{Variables of the study}

The physical activity places located near the household were evaluated by asking the following question: "In a normal week, do you go to these places near your residence (10-15 minutes walking) to practice any physical activity?" The options of answers for the places (park, square, walking/running track, cycle paths, soccerfields, gymnasiums or sports courts, gyms, clubs, outdoor gyms, skateboarding bowls, school and others) ranged from 0-7 days/week. For the purposes of analysis, they were categorized into: 0 "does not go" and $\geq 1$ "goes".

The physical activity practiced by the adolescents was evaluated using the Physical Activity Questionnaire for Adolescents (QAFA), ${ }^{17}$ which includes a list of 24 activities, and the adolescents could add activities other than those listed. For the purposes of description, it was determined whether the adolescent does not do any physical activity ( 0 min/week) or does some physical activity ( $\geq 1 \mathrm{~min} /$ week).

From the physical activities listed in the QAFA, the adolescents were asked about the usual activities practiced during the week in their free time. These activities were analyzed in three ways: frequency (days/ week), duration (minutes/day) and volume (minutes/week) by calculation [frequency * duration]. The activities were grouped into the five categories below: 1) Sports (soccer, indoor soccer, handball, basketball, skateboarding, athletics, rhythmic gymnastics, fights, volleyball, beach volleyball, tennis and beach soccer); 2) Physical conditioning (dancing, bodybuilding, crunches and push-ups and fitness activities); 3) Aerobics (running/jogging, cycling, walking, playing games and doing playful activities and walking the dog); 4) Water exercises (surfing, bodyboarding and swimming); 5) Active gaming. The latter was analyzed separately because of the growing debate and the adolescents'interest in interactive games and because they can be played in different places and intensities. ${ }^{18}$ Walking and cycling for commuting purposes were excluded from the analysis. The classification used followed the grouping suggested in the Compendium of Physical Activities. ${ }^{19}$ 
To describe the sample, the following variables were used: Sex of the adolescent registered by the interviewer, age was based on the date of birth until the date of the interview, then classified into three age groups ("12-13 years","14-15 years"and"16-17 years"). Body mass and height were measured directly using a scale and digital stadiometer (Brand:Wiso, Model:W721) and used to calculate Body Mass Index, in four categories:"underweight","normal weight", "overweight" and "obesity".20 Socioeconomic level was evaluated using a standardized questionnaire from the Brazilian Association of Survey Companies (ABEP). ${ }^{21}$ For the purposes of analysis, the socioeconomic level was grouped as "high" (classes A + B) and "low" (classes C+D+E).

\section{Data analysis}

The sample was characterized with distribution of absolute and relative frequency. The physical activity places frequented were described according to the sex. The types of physical activity were described according to usual practice, frequency (days/week), duration (minutes/day) and weekly volume (minutes/week). Data normality was confirmed using the Kolmogorov-Smirnov test and the data did not present normal distribution. Median and interquartile range were used to describe the results. Comparison between the proportions of the places frequented and practice of physical activity was made with the Chi-square test and Fisher's exact test. Comparison of the variables of weekly frequency (days/week), duration (minutes/day) and volume (minutes/week) was made using the U Mann-Whitney test. All analyses were conducted using the software SPSS 20.0 and significance level of 5\%.

\section{RESULTS}

Of the adolescents identified ( $n=930$ ), the refusal rate for participation in the survey was $46.3 \%$, and the final sample was 495 adolescents (50.7\% girls). Most participants were aged 12-13 (41.4\%), were at a low socioeconomic level (59.0\%), presented normal nutritional status (58.3\%) and do some physical activity in their free time (77.2\%), with a higher proportion of boys $(p<0.001)$. (Table 1$)$

In general, the most frequented places were squares (27.2\%), parks (25.7\%), soccer fields (24.9\%), schools (22.8\%) and gymnasiums or sports courts (16.0\%). Among the boys, the most frequented places were soccer fields (37.5\%), squares (30.3\%), parks (28.4\%), schools (27.9\%) and gymnasiums or sports courts (21.6\%), while among the girls, squares (23.6\%), parks (22.4\%), gyms (18.4\%), schools (16.7\%) and outdoor gyms (15.5\%) were the most frequented places. A higher proportion of boys frequenting soccer fields $(p<0.001)$, schools $(p=0.009)$, gymnasiums or sports courts ( $p=0.001)$ and skateboarding bowls $(p=0.002)$ was found, while girls frequented more gyms $(p=0.020)$. (Figure 1 )

The physical activities most practiced by adolescents were soccer (27.9\%), skateboarding/rollerblading (22.6\%), cycling (18.8\%), walking

Table 1. Description of characteristics of study participants stratified according to the sex of adolescents. Curitiba-PR, 2013-2014 ( $n=495)$.

\begin{tabular}{c|c|c|c|c|c|c|c|c}
\hline \multirow{2}{*}{ Variable } & \multirow{2}{*}{ Category } & \multicolumn{2}{|c|}{ Male } & \multicolumn{2}{c|}{ Female } & \multicolumn{2}{c}{ Total } \\
\cline { 3 - 9 } & & $\mathbf{n}$ & $\%$ & $\mathbf{n}$ & $\%$ & $\mathbf{p}$ & $\mathbf{n}$ & $\%$ \\
\hline Sex & & 244 & 49.3 & 251 & 50.7 & - & 495 & 100.0 \\
\hline \multirow{2}{*}{$\begin{array}{c}\text { Age group } \\
\text { (years) }\end{array}$} & $12-13$ & 98 & 40.2 & 107 & 42.6 & 0.857 & 205 & 41.4 \\
\cline { 2 - 9 } & $14-15$ & 91 & 37.3 & 78 & 31.1 & & 169 & 34.1 \\
\cline { 2 - 9 } & $16-17$ & 55 & 22.5 & 66 & 26.3 & & 121 & 24.5 \\
\hline \multirow{2}{*}{$\begin{array}{c}\text { Nutritional } \\
\text { status (BM|*) }\end{array}$} & Low weight & 53 & 22.9 & 43 & 18.8 & 0.344 & 96 & 20.9 \\
\cline { 2 - 9 } & Normal weight & 132 & 57.1 & 136 & 59.4 & & 268 & 58.3 \\
\cline { 2 - 9 } & Overweight & 36 & 15.6 & 39 & 17.0 & & 75 & 16.3 \\
\cline { 2 - 9 } & Obesity & 10 & 4.3 & 11 & 4.8 & & 21 & 4.6 \\
\hline $\begin{array}{c}\text { Socioeconomic } \\
\text { level }\end{array}$ & Low & 99 & 40.6 & 96 & 38.2 & 0.596 & 292 & 59.0 \\
\hline & High & 145 & 59.4 & 155 & 61.8 & & 203 & 41.0 \\
\hline \multirow{2}{*}{\begin{tabular}{c} 
Physical activity \\
\cline { 2 - 8 }
\end{tabular}} & $\begin{array}{c}\text { Does not do } \\
\text { (0 min/week) }\end{array}$ & 36 & 14.8 & 77 & 30.7 & $<0.001$ & 113 & 22.8 \\
\cline { 2 - 8 } & $\begin{array}{c}\text { Does } \\
(\geq 1 \text { min/week) }\end{array}$ & 208 & 85.2 & 174 & 69.3 & & 382 & 77.2 \\
\hline
\end{tabular}

(18.0\%) and active gaming (16.6\%). Compared between the sexes, a greater proportion of boys reported cycling $(25.4 \% p<0.001)$, basketball (9.4\% $p=0.015)$, running/jogging (17.2\% $p=0.038)$, soccer $(44.7 \%, p<0.001)$, futsal $(13.9 \% p<0.001)$ and skateboarding/rollerblading $(29.1 \% p<0.001)$. Among the girls, the most practiced activities were walking (23.1\% $p=0.003)$, dancing (11.2\% $p<0.001)$, fitness activities (4.8\% $p=0.012)$, handball ( $2.4 \% \mathrm{p}=0.030)$, playing games and doing playful activities $(5.6 \% \mathrm{p}=0.041)$ and walking the $\operatorname{dog}(19.5 \% \mathrm{p}=0.020)$. (Table 2$)$

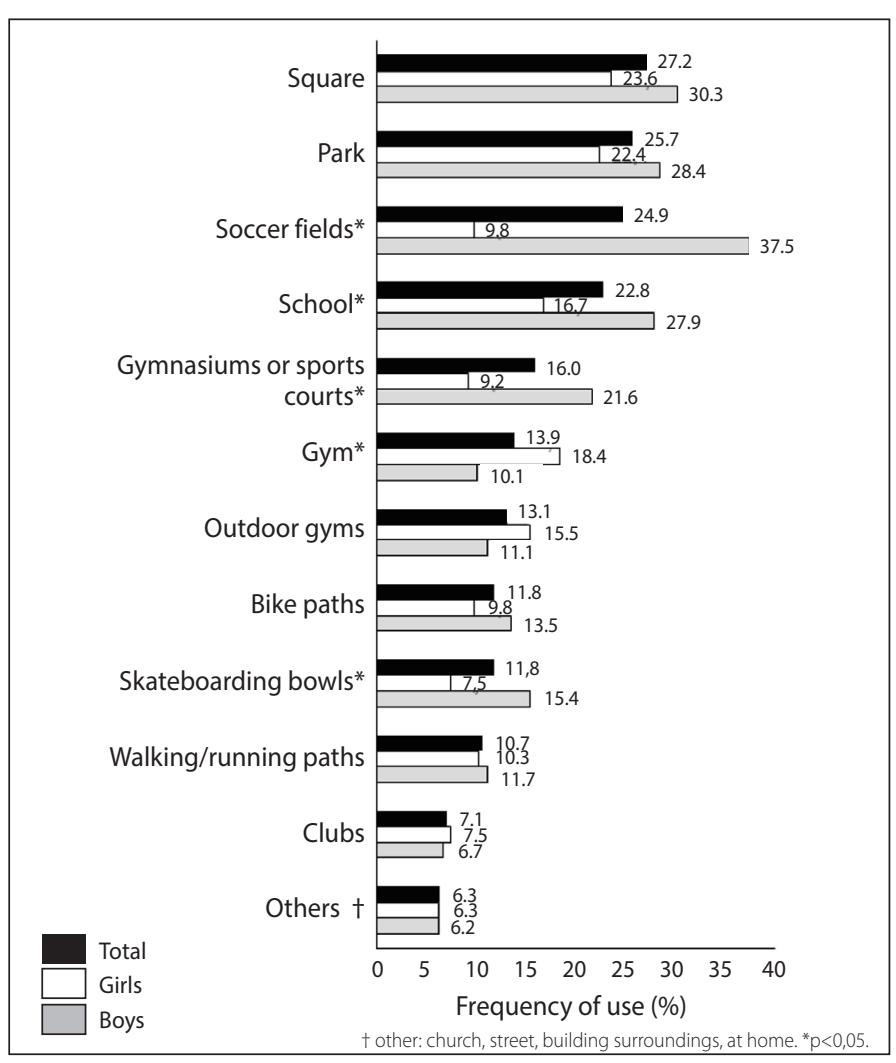

Figure 1. Description of the places for the practice of physical activity of the study participants stratified according to their sex. Curitiba-PR, 2013-2014 ( $n=382)$.

Table 2. Description of the type of physical activity practiced by adolescents according to sex. Curitiba-PR, 2013-2014 ( $n=382$ ).

\begin{tabular}{c|c|c|c|c|c|c|c}
\hline \multirow{2}{*}{ Activity } & \multicolumn{2}{|c|}{ Male } & \multicolumn{2}{c|}{ Female } & \multicolumn{2}{c}{ Total } \\
\cline { 2 - 8 } & $\mathbf{n}$ & $\%$ & $\mathbf{n}$ & $\%$ & $\mathbf{P}$ & $\mathbf{n}$ & $\%$ \\
\hline Soccer & 109 & 44.7 & 29 & 11.6 & $<0.001^{\mathrm{h}}$ & 138 & 27.9 \\
\hline Skateboarding/Rollerblading & 71 & 29.1 & 41 & 16.3 & $0.001^{\mathrm{h}}$ & 112 & 22.6 \\
\hline Cycling & 62 & 25.4 & 31 & 12.4 & $<0.001^{\mathrm{h}}$ & 93 & 18.8 \\
\hline Walking & 31 & 12.7 & 58 & 23.1 & $0.003^{\mathrm{h}}$ & 89 & 18.0 \\
\hline Active gaming & 44 & 18.0 & 38 & 15.1 & $0.387^{\mathrm{h}}$ & 82 & 16.6 \\
\hline Walking the dog & 29 & 11.9 & 49 & 19.5 & $0.020^{\mathrm{h}}$ & 78 & 15.8 \\
\hline Running/jogging & 42 & 17.2 & 27 & 10.8 & $0.038^{\mathrm{h}}$ & 69 & 13.9 \\
\hline Volleyball & 19 & 7.8 & 30 & 12.0 & $0.121^{\mathrm{h}}$ & 49 & 9.9 \\
\hline Crunches and push-ups & 23 & 9.4 & 22 & 8.8 & $0.798^{\mathrm{h}}$ & 45 & 9.1 \\
\hline Indoor soccer & 34 & 13.9 & 8 & 3.2 & $<0.001^{\mathrm{h}}$ & 42 & 8.5 \\
\hline Bodybuilding & 17 & 7.0 & 25 & 10.0 & $0.232^{\mathrm{h}}$ & 42 & 8.5 \\
\hline Basketball & 23 & 9.4 & 10 & 4.0 & $0.015^{\mathrm{h}}$ & 33 & 6.7 \\
\hline Dancing & 2 & 0.8 & 28 & 11.2 & $<0.001^{\mathrm{f}}$ & 6.1 & 6.1 \\
\hline Fighting & 19 & 7.8 & 10 & 4.0 & $0.072^{\mathrm{h}}$ & 29 & 5.9 \\
\hline Games and playful activities & 5 & 2.0 & 14 & 5.6 & $0.041^{\mathrm{h}}$ & 19 & 3.8 \\
\hline Fitness activities & 2 & 0.8 & 12 & 4.8 & $0.012^{\mathrm{f}}$ & 14 & 2.8 \\
\hline Swimming & 5 & 2.0 & 6 & 2.4 & $0.797^{\mathrm{h}}$ & 11 & 2.2 \\
\hline Field tennis & 3 & 1.2 & 4 & 1.6 & $1.000^{\mathrm{f}}$ & 7 & 1.4 \\
\hline Handball & 0 & 0.0 & 6 & 2.4 & $0.030^{\mathrm{f}}$ & 6 & 1.2 \\
\hline Athletics & 1 & 0.4 & 1 & 0.4 & $1.000^{\mathrm{f}}$ & 2 & 0.4 \\
\hline Beach soccer & 1 & 0.4 & 1 & 0.4 & $1.000^{\mathrm{f}}$ & 2 & 0.4 \\
\hline Fitness activities & 0 & 0.0 & 2 & 0.8 & $0.499^{\mathrm{f}}$ & 2 & 0.4 \\
\hline Beach volley & 1 & 0.4 & 1 & 0.4 & $1.000^{\mathrm{f}}$ & 2 & 0.4 \\
\hline
\end{tabular}

Chi-square for heterogeneity; fischer's exact test; $p<0.05$. 
Sports (720 min/week), aerobic activities (400 min/week) and physical conditioning (345 min/week) were the activities with the highest weekly volume. Boys do sports with more weekly frequency, duration and weekly volume $(p<0.001)$ and active games with higher frequency and weekly volume compared with girls $(p<0.05)$. No significant differences were observed in the other groups of activities. (Table 3 )

\section{DISCUSSION}

This was one of the first studies describing in detail the places where adolescents practice physical activities and the types, weekly frequency and duration of exercising in Curitiba-PR. Most studies have reported levels of physical activity related to recommendations and associated factors., ${ }^{8} 22$ Although these levels are measured using questionnaires - a subjective measure - this allows to describe the places and the most popular activities, which is one of the strengths of the study.

In this study, public spaces were the most frequented ones by adolescents practicing physical activity. In data obtained through systematic observation of parks and squares in the city of Curitiba, adolescents represent 14 to $35 \%$ of users, despite the great variation on the days of the week and time of day. ${ }^{23}$ To some extent, the results could be explained by the large availability of parks, squares in the city, ${ }^{10}$ and facilities that include sports gyms and the use of school facilities in certain periods. ${ }^{13,24}$ As living near these places is associated with higher levels of physical activity, it should be noted that the presence of adequate structures and the availability of activities are associated with greater chances of using these spaces. In a study conducted in the United States, in outdoor areas, adolescents were more likely to engage in activities of higher intensities. ${ }^{25}$

The physical activities most reported by boys were soccer, skateboarding/rollerblading , cycling, active gaming, running/jogging and indoor soccer, while girls reported walking, walking the dog, skating/rollerblading, active gaming, cycling and volleyball. Soccer ranking at the top of the most practiced activities, especially by boys, reflects the country's social and cultural concerns, ${ }^{5}$ as sports are usually one of the main contents of Physical Education classes in school. Besides that, similar results were found in other studies. ${ }^{6,7}$ Although results shows soccer was the most performed activity between youth, in adults there is a reduced proportion of practicioners. ${ }^{14}$

Activities such as skateboarding/rollerblading and cycling are among the most reported ones and tend to show a characteristic of the city of Curitiba, because of the setup of facilities associated with these activities. The city has been recognized as the Brazilian capital of skateboarding, ${ }^{26}$ especially due to the projects designed for the practitioners, besides the considerable number of athletes in the city, which contributes to the development of a culture around skateboarding. Regarding cycling, the city has an extensive network of bicycle paths that were implemented in the early 1970s. ${ }^{10}$ Besides this, the implementation of cycle lanes, calm roads, and oriented cycling programs has further supported bicycle use.

Walking is practiced by $18.0 \%$ of adolescents and is more frequent among girls. This practice is often low among adolescents and more common in female adults, ${ }^{7,14}$ contradicting the findings of this study. Despite the importance of active behaviors, activities of greater intensity that are appropriate to youth health should be encouraged.'

Active gaming was reported by $16.6 \%$ of adolescents. This activity points to a transition of the characteristics of video games which used to influence an increase of physically inactive behavior. ${ }^{27}$ A systematic review has suggested that this type of activity may provide physical activities of moderate intensity. ${ }^{27}$ However, further studies are needed to find out the extent to which these activities can replace other physical activities.

In the activities grouped by type, boys engage in sports activities and active gaming with more weekly frequency, duration and volume compared with girls. These results are consistent with those found in the literature. ${ }^{28}$ A longitudinal study found that boys tend to increase physical activity from childhood to adolescence, while the behavior of girls is the opposite. ${ }^{28}$ Understanding which factors explain this behavior, especially among girls, is an important step to mitigate or counteract the decline in physical activity levels. ${ }^{29}$ Although a study shows that engaging in sports does not reduce the decline of physical activity to adulthood, ${ }^{30}$ encouraging this practice may help maintain this behavior. ${ }^{2}$

Despite the importance of reporting the most frequented places and the physical activities performed, exploring the intrinsic and extrinsic factors for adopting these behaviors can help understanding these results.12,22 Therefore, offering physical activities in places and types of activities with adequate intensity and duration should be considered to reach out to the youth.

Some limitations should be considered in interpreting the results. The lack of studies reporting information about physical activities such as weekly frequency, duration and volume make it difficult to compare the results. The sample is not representative of local adolescents, as they were picked from intentionally selected census tracts. The use of questionnaires presents a limitation regarding the accuracy of the physical activities analyzed and a potential overestimation of the reported volumes.

Table 3. Description of the frequency, duration and volume of the types of physical activities stratified by the sex of the adolescents. Curitiba-PR, 2013-2014 ( $n=382$ ).

\begin{tabular}{|c|c|c|c|c|c|c|c|c|}
\hline \multirow{2}{*}{\multicolumn{2}{|c|}{ Type of physical activity }} & \multicolumn{2}{|c|}{ Male } & \multicolumn{2}{|c|}{ Female } & \multirow[b]{2}{*}{$p$} & \multicolumn{2}{|c|}{ Total } \\
\hline & & \multirow{2}{*}{$\begin{array}{c}\tilde{x} \\
4.0 \\
\end{array}$} & \multirow{2}{*}{$\begin{array}{c}\text { IQR } \\
5.0\end{array}$} & \multirow{2}{*}{$\begin{array}{c}\tilde{x} \\
2.0\end{array}$} & \multirow{2}{*}{$\begin{array}{c}\text { IQR } \\
3.0 \\
\end{array}$} & & \multirow{2}{*}{$\begin{array}{c}\tilde{x} \\
3.0 \\
\end{array}$} & \multirow{2}{*}{$\begin{array}{c}\text { IQR } \\
3.8\end{array}$} \\
\hline \multirow{3}{*}{ Sports $^{\mathrm{a}}$} & Weekly frequency (days/week) & & & & & $<0.001$ & & \\
\hline & Duration (minutes/day) & 120.0 & 120.0 & 60.0 & 90.0 & $<0.001$ & 90.0 & 103.8 \\
\hline & Weekly volume (minutes/week) & 360.0 & 900.0 & 120.0 & 310.0 & $<0.001$ & 285.0 & 720.0 \\
\hline \multirow{3}{*}{ Aerobics $^{b}$} & Weekly frequency (days/week) & 5.0 & 4.0 & 4.0 & 4.0 & 0.727 & 4.0 & 5.0 \\
\hline & Duration (minutes/day) & 60.0 & 90.0 & 55.0 & 50.0 & 1.000 & 60.0 & 50.0 \\
\hline & Weekly volume (minutes/week) & 240.0 & 400.0 & 150.0 & 408.7 & 0.744 & 180.0 & 400.0 \\
\hline \multirow{3}{*}{ Conditioning ${ }^{c}$} & Weekly frequency (days/week) & 4.0 & 4.0 & 3.5 & 4.0 & 0.506 & 4.0 & 4.0 \\
\hline & Duration (minutes/day) & 40.0 & 50.0 & 85.0 & 62.5 & 0.114 & 60.0 & 80.0 \\
\hline & Weekly volume (minutes/week) & 120.0 & 380.0 & 240.0 & 402.5 & 0.676 & 180.0 & 345.0 \\
\hline \multirow{3}{*}{$\begin{array}{l}\text { Sports and water } \\
\text { activities }^{d}\end{array}$} & Weekly frequency (days/week) & 2.0 & 2.0 & 2.0 & 1.0 & 0.792 & 2.0 & 1.0 \\
\hline & Duration (minutes/day) & 60.0 & 30.0 & 60.0 & 48.7 & 0.662 & 60.0 & 30.0 \\
\hline & Weekly volume (minutes/week) & 120.0 & 270.0 & 150.0 & 150.0 & 0.792 & 120.0 & 120.0 \\
\hline \multirow{3}{*}{ Active gaming } & Weekly frequency (days/week) & 3.0 & 5.0 & 1.5 & 2.2 & 0.011 & 2.0 & 4.0 \\
\hline & Duration (minutes/day) & 60.0 & 150.0 & 60.0 & 90.0 & 0.459 & 60.0 & 125.0 \\
\hline & Weekly volume (minutes/week) & 180.0 & 438.7 & 90.0 & 240.0 & 0.038 & 120.0 & 300.0 \\
\hline
\end{tabular}




\section{CONCLUSION}

Public facilities were the places most used to practice physical activity among adolescents. The most practiced activities were soccer, skateboarding/rollerblading, cycling, walking and active gaming. Sports were the predominant physical activities among the boys, while among the girls, lower-intensity and poorly-structured activities prevailed. Sports presented a higher weekly volume of practice, especially among boys, followed by aerobic and conditioning activities. Active gaming is performed more frequently and with a greater weekly volume among boys than girls. Activities aimed at this group should prioritize the most frequented places, provide adequate structures, and offer the types of activities that are most attractive to the youth, while considering sufficient intensity and volume to afford health benefits. Further studies should include a representative sample and examine potential relationships with socioeconomic and motivational characteristics.

\section{ACKNOWLEDGEMENTS}

The authors acknowledge the support of the households participating in the study and all members of the Research Group on Physical Activity and Quality of Life (GPAQ) in assisting data collection and Coordenação de Aperfeiçoamento de Pessoal de Nível Superior (CAPES) and National Institutes of Health (NIH) (Grant 56073B P1661 7811211) for financial support.

All authors declare no potential conflict of interest related to this article

AUTHORS' CONTRIBUTIONS: All authors declare no potential conflict of interest related to this article. AAPS (0000-0003-0442-4938)*: conception of the study, literature review, data collection, statistical analysis, interpretation of the results and writing up all stages of the study; EMC (0000-0003-2127-2606): literature review, data collection, statistical analysis, interpretation of the results and writing up all stages of the study; ATS (0000-0002-9286-4345)*: literature review, data collection, statistical analysis; AAFH (0000-0003-1649-9419)*: conception of the study, data collection, critical revision of the manuscript; RSR (0000-0002-9872-9865)*: conception and coordination of the project and critical revision of the manuscript. All authors approved the final version of the manuscript. *ORCID (Open Researcher and Contributor ID).

\section{REFERENCES}

1. Janssen I, Leblanc AG. Systematic review of the health benefits of physical activity and fitness in school-aged children and youth. Int J Behav Nutr Phys Act. 2010;7:40.

2. Viner RM, Ozer EM, Simon D, Marmot M, Resnick M, Fatusi A, et al. Adolescence and the social determinants of health. The Lancet. 2012;379(9826):1641-52

3. Cureau FV, Silva TLN, Bloch KV, Fujimori E, Belfort DR, Carvalho KMB, et al. ERICA: Leisure-time physical inactivity in Brazilian adolescents. Rev Saude Publica. 2016;50(1):1-11.

4. Oliveira JS, Barufaldi LA, Abreu GA, Leal VS, Brunken GS, Vasconcelos SML, et al. ERICA: use of screens and consumption of meals and snacks by Brazilian adolescents. Rev. Saude Publica. 2016;50.

5. Hulteen RM, Smith JJ, Morgan PJ, Barnett LM, Hallal PC, Colyvas K, et al. Global participation in sport and leisure-time physical activities: A systematic review and meta-analysis. Prev Med. 2017;95:14-25.

6. Azevedo Júnior MR, Araújo CLP, Pereira FM. Atividades Físicas e Esportivas na Adolescência: mudanças de preferências ao longo das últimas décadas. Revista Bras Educ Fis Esporte. 2006;20(1):51-58.

7. Freitas RWJF, Silva ARV, Araújo MFM, Marinho NBP, Damasceno MMC, Oliveira MR. Prática de atividade física por adolescentes de Fortaleza, CE, Brasil. Rev Bras Enferm. 2010;63:410-15.

8. Hallal PC, Knuth AG, Cruz DKA, Mendes MI, Malta DC. Prática de atividade física em adolescentes brasileiros. Cien Saude Colet. 2010;15:3035-42

9. Bauman AE, Reis RS, Sallis JF, Wells JC, Loos RJ, Martin BW. Correlates of physical activity: why are some people physically active and others not? Lancet 2012;380(9838):258-71.

10. Moysés SJ, Moysés ST, Krempel MC. Avaliando o processo de construção de políticas públicas de promoção de saúde: a experiência de Curitiba. Cien Saúde Colet. 2004;9:627-41.

11. Sallis JF, Cervero RB, Ascher W, Henderson KA, Kraft MK, Kerr J. An ecological approach to creating active living communities. Annu Rev Public Health. 2006;27:297-322.

12. Ding D, Sallis JF, Kerr J, Lee S, Rosenberg DE. Neighborhood environment and physical activity among youth a review. Am J Prev Med. 2011;41(4):442-55.

13. Lima AV, Fermino RC, Oliveira MP, Rodriguez Añez CR, Reis RS. Distância percebida até as instalações de lazer e sua associação com a prática de atividade física e de exercícios em adolescentes de Curitiba, Paraná, Brasil. Cad. Saude Publica. 2013;29:1507-21.

14. de Sa TH, Garcia LM, Claro RM. Frequency, distribution and time trends of types of leisure-time physical activity in Brazil, 2006-2012. Int J Public Health. 2014;59(6):975-82.

15. Dumith SC, Domingues MR, Gigante DP. Epidemiologia das atividades físicas praticadas no tempo de lazer por adultos do Sul do Brasil. Rev Bras Epidemiol. 2009;12:646-56

16. Alberico CO, Schipperijn J, Reis RS. Use of global positioning system for physical activity research in youth: ESPAÇOS Adolescentes, Brazil. Prev Med. 2017;103S:S59-65.
17. de Farias JC Jr, Lopes Ada S, Mota J, Santos MP, Ribeiro JC, Hallal PC. Validity and reproducibility of a physical activity questionnaire for adolescents: adapting the Self-Administered Physical Activity Checklist. Rev Bras. Epidemiol. 2012;15(1):198-210

18. Gomes J, Melo R, Oliveira S, Costa M. Exergames podem ser uma ferramenta para acréscimo de atividade física e melhora do condicionamento físico? Rev Bras Ativ Fis Saude. 2015;20(3):232.

19. Ainsworth BE, Haskell WL, Herrmann SD, Meckes N, Bassett DR Jr, Tudor-Locke C, et al. 2011 compendium of physical activities: A second update of codes and MET values. Med Sci Sports Exerc. 2011;43(8):1575-81.

20. Conde WL, Monteiro CA. Body mass index cutoff points for evaluation of nutritional status in Brazilian children and adolescents. J Pediatr (Rio J). 2006;82(4):266-72.

21. ABEP. Associação Brasileira de Empresas de Pesquisa (ABEP). Critério de classificação econômica Brasil. [acesso em 2016 nov 5]. Disponível em: http://www.abep.org/.

22. Fermino RC, Rech CR, Hino AAF, Rodriguez Añez CR, Reis RS. Atividade física e fatores associados em adolescentes do ensino médio de Curitiba, Brasil. Rev Saude Publica. 2010;44(6):986-95.

23. Hino AAF, Reis RS, Ribeiro IC, Parra DC, Brownson RC, Fermino RC. Using observational methods to evaluate public open spaces and physical activity in Brazil. J Phys Act Health. 2010;7(Suppl 2):S146-54.

24. Prefeitura Municipal de Curitiba. Informações sobre o Programa Comunidade Escola. [acesso em 2017 out 21]. Disponível em: http://www.comunidadeescola.org.br/conteudo/ informacoes-sobre-o-programa-comunidade-escola/88.

25. Oreskovic NM, Perrin JM, Robinson Al, Locascio JJ, Blossom J, Chen ML, et al. Adolescents' use of the built environment for physical activity. BMC Public Health. 2015;15:251.

26. Prefeitura Municipal de Curitiba. Curitiba comemora Dia Mundial do Skate. [acesso em 2017 out 21]. Disponível em: http://www.curitiba.pr.gov.br/noticias/curitiba-comemora-dia-mundial-do-skate/27063.

27. Brito-Gomes JL, Perrier-Melo RJ, Oliveira SFM, Costa MC. Exergames podem ser uma ferramenta para acréscimo de atividade física e melhora do condicionamento físico? Rev Bras Ativ Fis Saude. 2015;20(3):232-42.

28. Dumith SC, Gigante DP, Domingues MR, Hallal PC, Menezes AM, Kohl HW 3rd. A longitudinal evaluation of physical activity in Brazilian adolescents: tracking, change and predictors. Pediatr Exerc Sci. 2012;24(1):58-71

29. Sallis JF, Bull F, Guthold R, Heath GW, Inoue S, Kelly P, et al. Progress in physical activity over the Olympic quadrennium. Lancet. 2016;388(10051):1325-36.

30. Bélanger M, Gray-Donald K, O'Loughlin J, Paradis G, Hutcheon J, Maximova K, et al. Participation in organised sports does not slow declines in physical activity during adolescence. Int J Behav Nutr Phys Act. 2009;6(22):1-6. 